\title{
THE IOWA CONFERENCE ON LOCAL HISTORY
}

The first Iowa Conference on Local History, was held in Des Moines, Mary 9, 1941. Called by the Iowa State Department of History and Archives to consider the problems of the local historical societies, town, city, county, or district, the Conference had two major problems to consider: those of the interested individuals in communities where no historical societies then existed, and secondly the problems of groups already organized. The Conference was primarily concerned in the important contributions thoughtfully interested people and groups throughout the state could make to the regional history which they knew best.

A third consideration was present in calling the Conference. It was the belief shared by the American Association for State and Local History, of which the department is a member, that a serious attention given to local historical matters would produce a higher appreciation of our wider regional and national history, and further, that it would raise our standards of historical criticism.

The attendance and interest manifested in the Conference was amazing and highly gratifying for this experiment. Over a hundred people were in attendance, and twenty-seven counties were represented. Top honors for distance traveled was almost evenly shared by Des Moines, Foryette, Pottawattamie, and Woodbury counties, with the Fayette County Centennial Association having the largest delegation present.

The value of such a meeting as the May 9 Conference to the locally interested person and to the organized society was so apparent to those in attendance that it was unanimously decided to effect a permanent organization of such on Iowa Conference on Local History, as will be explained more fully later. 


\section{MORNING SESSION}

Ora Williams, Curator of the Iowa State Department of History and Archives, opened the Conference sessions by stating the simple purpose of the Conference: to coordinate, assist, and to stimulate the work of societies already organized, and to assist those interested individuals in communities where no local town or county organization existed.

\section{SUgGestions FOR NEW SOCIETIES}

Oliver W. Stevenson of Fayette, Iowa, opened the first session of the conference by introducing Henry K. Peterson of Council Bluffs, President of the Pottawattamie County Historical Society, who explained "How We Did It." That society, he disclosed, first began through the interest developed by Mr. O. J. Pruitt of Council Bluffs in the preservation of an abandoned cemetery in Mills County, to the south of Pottawattamie. The society continued to select specific and definite objectives in its first years of activity, such as the marking of several sites in the town of Council Bluffs, sites connected with pioneer days. Cooperation was easily found. The society finally incorporated, after a successful membership and financial drive, when it began to direct its efforts toward erecting a log cabin in the city park to house growing collections of the organization.

From Mr. Peterson's remarks it was apparent that intelligent and enthusiastic leadership, centered around definite objective programs, had borne results in an interested and live membership.

Dr. John Ely Briggs, editor of the publications of the State Historical Society of Iowa at Iowa City, in discussing "Suggestions for New Organizations," suggested to the Conference members that in their attempts at historical work they might find it helpful to remember that history can be reduced to the simple questions of Who Did What, When, Where, and Why. Or, What happened Where and Why did it. Of course, he explained, its the answers to these simple questions that bring the complications. 
Dr. Briggs further reminded his hearers that all local or county historical societies automatically become associate members of the State Historical Society of Iowa at Iowa City, and as such receive all their publications gratis: the Iowa Journal of History and Politics, the Palimpsest, as well as the various books published by that organization from time to time.

As splendid cores around which $\alpha$ new society might well build an attractive program, Professor Briggs suggested the collection of pictures and the gathering of museum objects still extant in the local community.

\section{How to ORGanize}

In the remaining minutes of the opening session, Kenneth E. Colton, of the Iowa State Department of History and Archives, offered suggestions to those from communities contemplating or desiring to establish a historical society in an area where none had previously existed. The steps, it was affirmed, would be much the same for either a town or a county society.

Reminding the Conference of the lessons to be learned from Mr. Peterson's presentation, Mr. Colton stated that the first objective was to find the interested people, not only for members, but for leadership. Among those whom one should consult would be:

1. Newspaper editors

2. County Superintendent of Schools

3. Principals or teachers in the high schools, or instructors in the local college

4. Librarians, especially the county seat librarians

5. Clergymen, of all denominations

6. Patriotic organizations, D.A.R., S.A.R., American Legion, and other veteran and ancestral societies.

7. Women's Clubs

8. Pioneer families, and their descendents

9. Professional organizations, the medical, legal, etc. branches 
10. Business groups, Farm Bureau, etc.

While perhaps not all of these groups would be interested in the full range of the local program, each at least would be interested in the development of their special sphere. And would grow to appreciate the others.

Besides reaching the people likely to be interested in laying plans for organizing a local society, one should carefully plan for the first or organizing meeting. The time and place should be such as to accommodate as large a group as possible, and should be easily accessible. Furthermore, the core of the initial program might well have some special event or theme or anniversary to celebrate, which in itself could draw and attract interest town or county wide.

A final suggestion was made by a member of the conference that the organizing group should look into the desirability of incorporating under the state law for non-profit organizations.

\section{Collection and Care of Historical Museum Materials}

Mrs. Gertrude Henderson, Curator of the Sioux City Public Museum, chairman of the morning's second session "CoLlection and Care of Historical Museum Materials," explained the procedures by which her institution accessioned incoming objects and kept track of them, a system based largely upon the procedures followed in the Iowa State Department of History and Archives. Mrs. Henderson further explained the close relationship between the Sioux City Public Museum and the public schools, and various study and hobby clubs as well.

Mr. Jack W. Musgrove, Museum Director of the Iowa Department of History and Archives, then spoke briefly on the specific subject of classifying and cataloging in a small museum. Though the problem can be very vexatious if not handled properly, it is relatively simple and easily done if properly planned, Mr Musgrove explained. Basicly three 
records should be kept of each item received by the museum.

1. Entry in the "Accession book" is usually the first step taken in cataloging a museum item. This entry should be in permanent black ink in a bound book or ledger, and should include a description of the item, who gave it, who found, who or what used it, when, where, etc. Since the collection will eventually grow, it is best to start right from the beginning to give each and every museum item a number. The best method is to mark the number upon the object in permanent ink, pasting a label upon an object encounters the danger of a lost or loosened label, and the consequence, oftentimes, is an impossibility of identifying the object.

Tags tied to the object are sometimes necessary, but should generally be avoided, as they not only have a tendency to spoil the neatness of a museum display, but likewise run into the same danger as a pasted label—of being torn off or lost.

2. A record of the article by class, such as gun, ship, flag, money, clothing, and type of clothing, etc. This should ordinarily be made on $a 3 \times 5$ card, preferably with a hole punched in the bottom so that it can be filed in library-type drawers. It should carry enough information to distinguish it from similar articles, but need not be so detailed as the accession record.

3. A list of donors of items received. This list is also preferably kept on cards, similar to those used for the record made above. A bound book, however, can be used, with the name of the donor entered alphabetically therein.

Suitable records, such as used in the State Department of History and Archives, were shown.

Mr. Musgrove concluded by cautioning ambitious local museums of the different societies against accepting too many loan exhibits. These are fruitful of much trouble later 
on by requests for their return, or by their not impossible loss and damage. An outright gift gives the society a freedom of operation not obtained otherwise. Occasions do arise, however, when a loan is desirable, but for the beginning institution should be rarely adopted as a matter of practice.

Before adjournment, Mrs. Henderson suggested to the Conference that it give thought during the noon recess to the advisability of a permanent organization of an Iowa Conference on Local History, and with that the morning session adjourned.

Between 12 and 2 o'clock a special displary of historical museum materials from the collections of the State Department of History and Archives was shown. The object of the display was to suggest a number of smaller museum items which are still common in most communities and which a local society could collect to begin a nicely balanced museum. The display inluded a warming pan, a butter mold, knives and forks, a pewter plate, various types of irons for pressing and ironing, a Paul Revere Lantern, snuffers, a slate. A Kentucky Long Rifle, powder horn, bullet pouch, and candle molds were among other items displayed.

\section{AFTERNOON SESSION}

On the assembling of the Conference at 2 o'clock, a motion was offered from the floor directing the Chairman to appoint a committee of three to draft proposals for the permanent formation of an Iowa Conference on Local History. The motion was unaminously adopted. Later authorized to icrease the committee to five, and to include representatives of the State Department of History and Archives and the State Historical Society at Iowa City as ex officio members, the chair appointed Henry K. Peterson of Council Bluffs Chairman, and Mrs. Gertrude Henderson of Sioux City, Mr. Oliver W. Stevenson of Fayette, Mr. W. S. Johnson of Newton, and Mr. Remley J. Glass of Mason City as addi- 
tional members of the Organizing Committee. Upon the petition of Mr. Stevenson, Mr. Walter H. Beall of West Union was appointed to the committee in his stead.

\section{Iowa as a Field of Historical Study}

Homer Calkins, President of the Ringgold County Historical Society, Chairman of the first afternoon session, introduced Professor Earle D. Ross of Iowa State College, who in discussing "Agriculture in on Agricultural State," emphasized that "properly considered, Agriculture is related intimately to all the other developments in the making of the state."

An adequate understanding of the role of agriculture in the community. Prof. Ross pointed out, would include the study of such factors as the relationship of geography to settlement, and the influence of the areas of production upon the location of settlements, their reach and their type. The sources of population, means of travel, land purchasecustoms and laws, and pioneer conditions, all dovetail into a study of the development of leading crops and the improvements in varieties of crops and breeds. Further, Dr. Ross explained, the introduction of farm machinery, the problems of markets and marketing systems, together with the other factors, had an important bearing upon social life in lowa, the institutions of the church, and the school, and agricultural organizations.

Citing the Annals of Iowa, the Iowa Journal of History and Politics, and the Palimpsest, and a number of biographical studies and recollections, all or many of which are found in most libraries, Professor Ross concluded by stressing the value of the written diaries, letters, account books, society minutes and other manuscript records of Iowa farmers and leaders in farm movements to a study of the important role of agriculture in the history of Iowa. In locating and preserving these materials, he added, the local society can render history an inestimable service. 
THE RICHES OF HISTORY AT HOME

In the "Riches of History at Home," Professor Charles J. Ritchey of Drake University continued further the discussion of the value of written manuscript records to a correct understanding of the trends and developments of our past. Remarking that it was too bad the writing of diaries has somewhat gone out of fashion, Professor Ritchey observed that often patient detective work is required to discover the letters and diaries that did exist, since frequently, especially if they had passed into the hands of the second and third generation, the present owners seldom realized the historical riches contained in some old box or trunk in an attic or barn. Citing personal experiences in connection with his own studies in American history, Professor Ritchey stressed the fact that in addition to recognizing their value, as interested historically minded people, we should look to their preservation. The faded ink, the illegibly smeared pencil mark, the fragile paper, the stained page, once tossed aside or burned, or allowed to disintegrate, has lost its treasure for ever.

An excellent means of preservation, it was urged, was the use of microfilm photography. This method has an additional value besides placing the record on inflammable film which would last as long as the best of rag paper. It enables the family, neighboring society, or public institution to retain the original copy and yet give you or your society its equivalent, a photographic reproduction.

\section{Activities for the Local Society and Public Relations}

Professor Francis I. Moats of Simpson College was introduced by Royal Holbrook of Cedar Rapids, chairman of the last afternoon session. Professor Moats explained briefly the work of the Warren County Historical Society in collecting the educational school records of that county, in cooperation with the county superintendent of schools and the State Department of History and Archives.

Although much progress has been made in this county- 
wide project, Dr. Moats noted as a cautionary warning to other societies, not to delay too long in similar activities, that letters widely circulated to all school officials by the society found frequent instances of missing records even in the larger schools. Nevertheless, from the materials already located, Dr. Moats believed that the story of education in Warren County could be well reconstructed, full of its lessons of trials and success.

\section{PHOTOGRAPHS ARE HISTORICAL}

Slides from the large collection belonging to the Des Moines Pioneer Club were shown on a screen, as representative of what could be done by other local organizations in preserving a pictorial record of their historical, industrial, commercial, and social development as a community. The conference was reminded that pictures of modern buildings, present day people, and of contemporary events were historical as much as those of forty and a hundred years ago.

\section{THINGS WE CAN ALL DO}

Speaking on this topic Mr. Colton of the State Department of History and Archives, stressed the importance of planning a year round program. It was desirable for each society to frame a yearly objective, or an even longer ranged plan for activity. The program should be such as would carry over beyond and between the annual or periodic meetings of the society. For young societies specific objectives well within the reach of a year's program should be selected until sufficient experience is gained to attempt the more ambitious plans.

Objects or programs could easily be of any variety or scope. Of several which might be suggested, Mr. Colton reminded the Conference of Dr. Briggs' suggestion earlier in the day, the collecting of historical photographs. The Pioneer Club had amply demonstrated what could be done with such a program. Photographs can be used not only as a program of collection for a society, but as a stimulomt 
to public interest as well. The organization might sponsor a contest for the oldest photograph of the community or county, with prizes for the best in a given period, of a given subject or field, such as sports, social gatherings, governmental units and figures within the county, farm or industrial machinery, etc. Or a contest could be staged using the reverse techniques, such as an identification of certain selected photographs displayed in store windows. Such a program, it was stated, would stir up a surprising amount of interest in the local society.

Among the worth while activities recommended for the older and stronger societies $\mathrm{Mr}$. Colton urged a survey of the leading local or county newspapers with a view of making a concerted effort to discover missing issues and to complete the files in so far as possible. When missing issues have been uncovered, these should be presented to some central institution, the museum-library of the society, if it is large enough and so established, or to the local library if arrangements have been made with it, or, if desired, to the State Department of History and Archives to add to their large collection.

As an aid to this survey, a mimeographed form was suggested, to be circulated through the county by the members of the society. Or one could obtain an equally good coverage through the cooperation of the local news editor in announcement and by printing the form in the paper. $A$ similar plan of mimeographed slips could be used by the more experienced societies in making a thorough check and survey of the existence of valuable diaries and collections of letters of prominent lowans in their community.

Of course, a major objective of all societies could be a preparation for the centennial of the statehood of Iowa in 1946.

Meetings of the whole society's membership should have a definite regularity and cause, purpose or program. Themes might well be selected as various local anniversaries of events-such as, the Pioneer Lawyer, the Pioneer Doctor, Pioneer Mothers, Music, Politics( staging a drama- 
tization of a heated local election, national or state), Sports, or other similar ideas. Unless well organized, full meetings of the entire membership should not be too frequent.

At the close of Mr. Colton's remarks, Henry K. Peterson on behalf of the committee presented the report of the Organizing Committee for the Iowa Conference on Local History. The committee announced that it would meet in Des Moines within thirty days, at the call of the chairman, to make definite plans for the permanent organization of an Iowa Conference on Local History. The committee further recommended that a second Conference be called by the State Department of History and Archives to meet in Des Moines in the fall of 1941. The report was unaminously adopted, and the meeting and Conference adjourned.

\section{$* * * *$}

The Organizing Committee appointed by the Iowa Conference on Local History May 9, met in Des Moines June 7. All members were present, including representatives from the ex officio institutions. Upon the invitation of the chairman, Miss Charlotte Crosley of Webster City was present to give representation to the north and west-central district of the state.

After fully canvassing the subject the committee voted in favor of effecting a formal and permanent organization of an Iowa Conference on Local History, and set up the necessary committees to accomplish that purpose. It was the unaminous decision of the committee that a state-wide conference of all historical organizations in the state, and interested individuals as well, be summoned in October.

A committee to draft articles of incorporation for such a conference, as well as to draw up a proposed model of articles of incorporation for local county or town societies was appointed by Mr. Henry K. Peterson. With Remley J. Glass of Mason City as chairman, the other members were Mrs. Gertrude Henderson of Sioux City, and Miss Charlotte Crosley of Webster City. A program committee with power to select the date and aggenda of the fall meeting was also 
appointed, consisting of Walter H. Beall of West Union as Chairman, and Miss Eythl E. Martin of the State Historical Society at Iowa City, and Kenneth E. Colton of the Iowa Department of History and Archives as additional members.

The Organizing Committee strongly urged all communities and local historical societies in Iowa to plan an affiliation with the projected organization. The Committee recommended to all communities or districts which now have no formally organized historical group representing the whole community or area, to effect an organization by early fall and thus insure an institutional representation at the fall conference.

An added reason communities considering the steps of organization should complete them as early as possible is that they must be listed soon in order to be included in the new "Handbook of Historical Societies of United States and Canada," which the American Association for State and Local History is to publish this fall. All societies at present organized should be sure that formal notice of that fact is in the hands of Kenneth E. Colton of the State Department of History and Archives, Des Moines. 
Copyright of Annals of Iowa is the property of State of Iowa, by \& through the State Historical Society of Iowa and its content may not be copied or emailed to multiple sites or posted to a listserv without the copyright holder's express written permission. However, users may print, download, or email articles for individual use. 